DOI https://doi.org/10.30525/978-9934-26-040-7-2

\title{
ЧИ Є ВРЕГУЛЮВАННЯ СПОРУ ЗА УЧАСТЮ СУДДІ ЗГІДНО ЧИННОГО ЗАКОНОДАВСТВА УКРАЇНИ ПРИСУДОВОЮ МЕДІАЦІЕЮ?
}

\author{
Гаврилюк Р. О. \\ доктор юридичних наук, дочент, \\ завідувач кафедри публічного права \\ Чернівецького національного університету імені Юрія Федьковича \\ м. Чернівиі, Украӥна
}

Феномен медіації - ровесник людської цивілізації. На різних етапах іiі еволюції медіація відігравала різну роль. 3 появою потестарних суспільств, особливо держав із їх судами, на тривалий історичний період медіація була відкинута владними елітами на закутки суспільств. I лише повний параліч державного судочинства змусив соціуми знову вдатися до медіації як способу вирішення спорів, але уже в сучасних іiї формах. Спершу це сталося в останній чверті XX ст. у США та деяких інших країнах американського континенту, пізніше у країнах Свропи, Азії, Австралії, у ряді інших держав світу. Запровадження у них медіації як альтернативного судочинству способу вирішення спорів врятувало від руйнувань їх соціуми та держави

Із здобуттям Україною державної незалежності та початком реалізації нею загальноцивілізаційної матриці суспільного розвитку проблеми, які породили необхідність медіації у вищезазначених країнах, з усією гостротою постали і перед Україною. Зовнішнім проявом цих проблем і водночас спробою певним чином зреагувати на них стали перманентні реформи державного судочинства. Однак ці реформи не зробили його спроможнішим вирішувати лавиноподібно наростаючий обсяг спорів, які породжує суспільство, що вивільняється від адміністративно-командної системи. Першою вимушеною реакцією парадигмального рівня Української держави на вищезазначену ситуацію стало внесення змін у 2016 р. у розділ «Правосуддя» іiі Конституції, зокрема, у статтю 124 , яку було викладено у принципово зміненій редакції: «Юрисдикція судів поширюється на будь-який юридичний спір та будь-яке кримінальне обвинувачення. У передбачених законом випадках суди розглядають також інші справи. Законом може бути визначений обов'язковий досудовий порядок 
урегулювання спору» [1]. Об'єктивною метою нової фундаментальної конституційної конструкції було створення можливостей для подолання колапсу судової системи України у парадигмально інший спосіб, ніж їх пропонували уже декілька попередніх «реформ» вітчизняного судочинства.

Як уже зазначалося вище, для усього цивілізованого світу таким «парадигмально іншим способом стала медіація. Вона вивільнила судові системи відповідних країн від величезної кількості справ, здешевивши цим самим судочинство, запропонувала матрицю вирішення спорів самими їх учасниками, що не тільки різко збільшило ефективність вирішення спорів, але й трансформувало сторони спору із об'єктів судової процедури у суб'єктів медіації, стало історичним проривом у гарантуванні відповідними державами та позадержавними інституціями людської гідності.

В Україні невдовзі після внесення вищезазначених змін у Конституцію держави та на їх «втілення» у життя було прийнято Закон України «Про внесення змін до Господарського процесуального кодексу України, Цивільного процесуального кодексу України, Кодексу адміністративного судочинства України та інших законодавчих актів» від 3 жовтня 2017 р. №2147-VIII [2]. Однією із новел інституційного типу цього закону стало запровадження процедури мирного врегулювання спору за участю судді. Проте, як засвідчив подальший перебіг розгляду судових спорів, це мало що змінило у природі розгляду спорів сторін: на процедуру врегулювання спору за участі судді відводиться не більше тридцяти днів, в той час як судовий розгляд відповідних справ зазвичай триває роками; суддя наділений правом за власною ініціативою ще раніше перервати перебіг цього строку, якщо за його суб'єктивним переконанням будь-яка із сторін спору «затягуватиме» його врегулювання, без чіткого визначення законодавцем ознак такого «затягування». Тобто, в Україні навіть після вищезазначених конституційних і законодавчих змін судовий спір продовжує залишатися «власністю» судів і суддів, а не сторін спору.

Національна модель врегулювання спору за участю судді, запропонована законодавцем, виявилася неефективною. Основною причиною цього $є$ те, що дана модель продовжує залишатися у парадигмальних межах судочинства. Вона суперечить природі медіації $\mathrm{i}$ навіть процедурі консиліації, з якою досить подібна за зовнішніми ознаками, проте не за іiі властивостями. Адже консиліатор також призначається за добровільною згодою сторін. Його функція полягає у неупередженому 3'ясуванні обставин спору та наданні конкретних пропозицій сторонам для врегулювання спору між ними, які, звернімо 14 
увагу, не є обов'язковими для сторін. Ще однією фундаментальною відмінністю між класичною консиліацією та врегулюванням спору за участю судді відповідно до вітчизняного законодавства є та обставина, що консиліатор обирається сторонами за їх згодою, в той час як сторони спору не мають жодного стосунку до визначення судді, котрий відкриває провадження у справі і котрий в силу цього наділений законодавчим повноваженням врегульовувати спір шляхом мирного його вирішення. Саме тому юридична конструкція інституту врегулювання спору за участю судді, виписана законодавцем України, не є за ії правовою природою присудовою медіацією.

Однією з причин цього явища $є$ та обставина, що практично усі доктринальні розробки медіації як феномену, які в останні роки помітно активізувалися в Україні, зосереджені навколо зовнішньої, позасудової медіації, яка не $\epsilon$ інтегрованою у судовий процес. Натомість питання присудової медіації залишаються малодослідженими та недооціненими. Досвід багатьох європейських країн свідчить про значні переваги такого виду медіації. Більше того, багато експертів схиляються до думки, що для успішності медіації як суспільного феномену важливим та визначальним є ставлення суддів та судів до неї [3]. Присудова медіація може сприяти в Україні швидшому поширенню інформації про таку послугу, що надаватиме можливість для учасників судового провадження в Україні можливість здійснювати вибір між стратегіями «перемога-перемога» (медіація) та «перемогапрограш» (судочинство).

Присудова медіація (court-annexed mediation, court-related mediation) - це модель медіації інтегрованої у судове провадження. Вона проводиться після звернення осіб до суду. Ключовою ії особливістю $\epsilon$ те, що предмет спору став предметом судового провадження. Світовий досвід показує, що така медіація може здійснюватися за згодою сторін або за рекомендацією чи призначенням судді. Як правило, дана модель медіації передбачає іiї проведення суддями, які пройшли спеціальне навчання, або працівниками, персоналом суду чи помічниками суддів, чи персоналом інституцій альтернативного вирішення спорів, які функціонують при суді.

На нашу думку, для України буде корисним творчо запозичити досвід Нідерландів, де успішно реалізовується два різновиди присудової медіації: 1) внутрішня присудова медіація (internal courtannexed mediation) - проводиться самими суддями чи їх помічниками, або іншими працівниками суду та 2) зовнішня присудова медіація (external court-annexed mediation) - проводиться незалежними професійними медіаторами, які залучаються судом. Не менш широкі 
варіативні способи пропонування присудової медіації сторонам. Це може бути: 1) письмове направлення судді після звернення до суду, але перед початком судового провадження; 2) усне направлення суддею під час судового засідання; 3) самонаправлення - сторони під час судового провадження можуть самостійно заявити про потребу скористатись процедурою присудової медіації.

Слід зазначити, що після процедури направлення на медіацію в Нідерландах судове провадження призупиняється на термін до 3-х місяців, який, за потреби, може бути продовжений. Але й тут сторін не залишають сам на сам 3 їх спором. Так, спеціальні представники 3 питань медіаціï (mediation officers), які очолюють офіси 3 адміністрування медіації в судах і $є$ контактними особами для учасників судових проваджень, забезпечують сторін спору інформацією про принципи та особливості процедури медіації, допомагають їм працювати з реєстрами медіаторів та їх вибором, що дозволяє швидко, впродовж 48 годин після направлення сторін на медіацію, підписати угоду про проведення медіації.

Узагальнюючи досвід Нідерландів, можемо зауважити, що вони зуміли успішно поєднати, здавалося б, непоєднувані речі - медіацію та судочинство. Вони скористались перевагами кожного 3 цих процесів: швидкістю, гнучкістю, неформалізованістю процедури медіації та можливістю отримати офіційне рішення, затверджене та визнане судом, яке вони виробили самостійно.

Висновки. Інститут врегулювання спору за участю судді, запроваджений українським законодавцем у жовтні 2017 р., за його правовою природою протилежний класичним інститутам присудової медіації, які успішно зарекомендували себе у багатьох країнах світу. Врегулювання спору за участю судді продовжує перебувати у парадигмальних межах судочинства та суперечить усім канонам альтернативних судочинству методів вирішення спорів між їх сторонами. Запроваджуючи інститут врегулювання спору за участю судді, законодавець України не скористався наданою йому Конституцією України можливістю визначити обов'язковий позасудовий порядок врегулювання спорів. Причини цього явища сягають своїми коренями домінуючих світоглядних підвалин державницьких і політичних еліт України, суспільства в цілому та буттєвого устрою українського соціуму. Україна іманентно потребує коперниканського світоглядного перевороту у ставленні до медіації як до цивілізованого та ефективного способу вирішення спорів. 


\title{
Література:
}

1. Закон України «Про внесення змін до Конституції України (щодо правосуддя) від 2 червня 2016 р. // База даних «Законодавство України». URL: https://zakon.rada.gov.ua/laws/show/1401-19\#n2

2. Закон України «Про внесення змін до Господарського процесуального кодексу України, Цивільного процесуального кодексу України, Кодексу адміністративного судочинства України та інших законодавчих актів» // Електронний ресурс. - Режим доступу: https://zakon.rada.gov.ua/laws/show/2147\%D0\%B0-19

3. Див: Gap-Аналіз впровадження інституту медіації в Україні, підготовлений в рамках реалізації проекту СС Право-Justice. 2020. - С. 10-12 // Електронний ресурс: режим доступу: https://www.pravojustice.eu/storage/app/uploads/public/5f5/f7d/2a9/5f5f7d2 a9b5cb356474501.pdf

DOI https://doi.org/10.30525/978-9934-26-040-7-3

\section{ПОЛІТИКА ТА ЗАКОНОДАВСТВО ПНР ЩОДО НАЦІОНАЛЬНИХ МЕНШИН}

\author{
Дедурін Г. Г. \\ кандидат історичних наук, доцент, \\ доиент кафедри теорії та історії держави і права \\ факультету № 1 \\ Харківського начіонального університету внутрішніх справ \\ м. Харків, Україна
}

Геополітичні наслідки Другої світової війни привели не тільки до зміни характеру польської держави, яка перетворилася на Польську народну республіку (ПНР) - країну соціалістичного табору, але й істотно відкоригували державний курс щодо національних меншин. Нацистська окупаційна політика, спрямована на знищення цілих національних груп, як-то євреїв, циган, а також повоєнна зміна кордонів, особливо на сході, спричинили істотні зміни у національній структурі Польщі у порівнянні 3 міжвоєнним періодом. 3 перших повоєнних років польська комуністична влада була налаштована на побудову централізованої держави у якій не залишилось би місця 